Kuiken, K. A. \& Lyman, C. M. (1948). F. Nutr. 36, 359.

Liener, I. E. (1950). Trans. Amer. Ass. Cereal Chem. 8. 162.

Lyman, C. M. \& Kuiken, K. A. (1949). Bull. Tex. agric. Exp. Sta. no. 708.

McCance, R. A. \& Widdowson, E. M. (1946). Spec. Rep. Ser. med. Res. Coun., Lond., no. 235.

Rose, W. C. (1949). Fed. Proc. 8, 546.

Rose, W. C., Oesterling, M. J. \& Womack, M. (1948). F. biol. Chem. 176, 753.

Rosenberg, H. R. \& Rohdenburg, E. L. (195I). F. Nutr. 45, 593.

Stokes, J. L., Gunness, M., Dwyer, I. M. \& Caswell, M. C. (1945). F. biol. Chem. 160, 35.

Vijayaraghavan, P. K. \& Srinivasan, P. R. (1953). F. Nutr. 5I, 26I.

Widdowson, E. M. (1947). Spec. Rep. Ser. med. Res. Coun., Lond., no. 257.

Widdowson, E. M. \& McCance, R. A. (1954). Spec. Rep. Ser. med. Res. Coun., Lond., no. 287.

\title{
Antibiotic and Copper Supplements for Fattening Pigs
}

\author{
By R. S. BARBER, R. BRAUDE AND K. G. MITCHELL \\ National Institute for Research in Dairying, University of Reading
}

(Received I6 May 1955)

Barber, Braude, Mitchell \& Cassidy (1955) reported observations suggesting an improvement in the rate of growth of fattening pigs given a high-copper mineral supplement in the diet. These observations were later confirmed in a field trial involving eight centres and 182 pigs (Bowler, Braude, Campbell, Craddock-Turnbull, Fieldsend, Griffiths, Lucas, Mitchell, Nickalls \& Taylor, 1955). The responses obtained with the high-copper diets resembled in many ways those repeatedly obtained at Shinfield under similar environmental conditions by the feeding of antibiotics (Barber, Braude, Kon \& Mitchell, 1953; Barber, Braude \& Mitchell, r953, 1954). In view of this similarity and the possibility that the copper might have some bactericidal action in the pig's intestine, it was considered of interest to compare the effects of the copper and antibiotic supplements and to determine whether there was any synergic action between the two.

\section{EXPERIMENTAL}

The composition of the basal diet is given in Table I. The mineral supplement XF (a proprietary mixture supplied by Minsal Ltd, Northwich), consisted mainly of calcium oxide, sodium chloride with $4 \%$ of copper sulphate, a small amount of ferrous sulphate and traces of manganese sulphate, cobalt sulphate and potassium iodide.

Table I. Percentage composition of the basal diet

$\begin{array}{ll}\text { Barley meal } & 30 \\ \text { Fine wheat offal } & 50 \\ \begin{array}{l}\text { Flaked maize } \\ \text { White fish meal }\end{array} & \text { 10 } \\ \text { Rovimix (Roche Products Ltd) (containing 50,000 i.u. } & 4.5 \mathrm{~g} / 100 \mathrm{lb} . \\ \text { vitamin A and 5000 i.u. vitamin } D_{3} / \mathrm{g} \text { ) } & \end{array}$


The five treatments are shown in Table 2. In addition to the treatments $(I-4)$ in which the effects of the high-copper mineral and antibiotic supplements were compared, a fifth treatment (5) was included in which copper sulphate was added to the basal diet in amounts equivalent to that supplied by the mineral supplement XF (250 p.p.m. of copper).

Table 2. Treatments, mean live-weight gain, food consumption and efficiency of food utilization of pigs during the 15 weeks fattening period beginning at 10-1 I weeks of age

$\begin{array}{lcc}\text { Treatment no. } & \ldots & \text { I } \\ \text { Dietary supplement... } & \text { None }\end{array}$

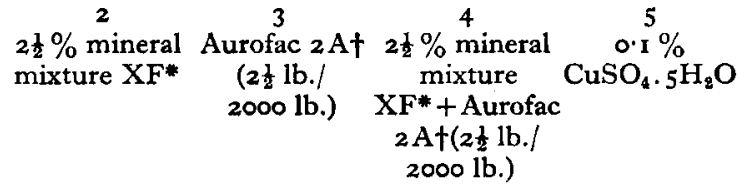

No. of pigs

Initial weight (lb.)

Live-weight gain (lb.):

In 15 weeks $t$

In first 8 weeks

In last 7 weeks

Food consumed (lb./pig):

In 15 weekst

In first 8 weeks

In last 7 weeks

6

$46 \cdot 0$

$146 \cdot 2$

$66 \cdot 2$

$80 \cdot 0$

$510 \cdot 3$

200.9

$309 \% 4$

6
$44 \cdot 7$
$156 \cdot 2$
$78 \cdot 7$
$77 \cdot 5$

$555^{\circ} \circ$

$222 \cdot 2$

$332 \cdot 8$
6

163.0

$80 \cdot 8$

$8 \mathbf{2} \cdot \mathbf{2}$

$554^{\prime} 2$

$221 \cdot 4$

$332 \cdot 8$

$\begin{array}{rr}6 & 6 \\ 44 \cdot 8 & 44 \cdot 8 \\ 158 \cdot 5 & 157 \cdot 7 \\ 77 \cdot 8 & 71 \cdot 7 \\ 80 \cdot 7 & 86 \cdot 0\end{array}$

$542 \cdot 2 \quad 5$ II 5

$214^{\circ} 3 \quad 192 \cdot 9$

$327.9 \quad 318.6$

Food consumed (lb./lb. live-weight gain):

In 15 weeks $\ddagger$

In first 8 weeks

3.49

3.04

In last 7 weeks

$3 \cdot 88$

3.55
$2 \cdot 83$
4.30

3.40
2.74
4.06

* Replacing $2 \frac{1}{2} \%$ barley meal.

† Lederle Laboratories Inc., containing $3.6 \mathrm{~g}$ aureomycin (chlortetracycline)/lb.

In an analysis of variance the differences between means necessary for significance were:

\begin{tabular}{|c|c|c|c|c|}
\hline & \multicolumn{3}{|c|}{ Level of significance } & \multirow{2}{*}{$\begin{array}{c}\text { Coefficient } \\
\text { of variation } \\
(\%)\end{array}$} \\
\hline & $5 \%$ & $1 \%$ & $0.1 \%$ & \\
\hline $\begin{array}{l}\text { For live-weight gain } \\
\text { For amount of food consumed per pig }\end{array}$ & $\begin{array}{r}8 \cdot 99 \\
32 \cdot 26\end{array}$ & $\begin{array}{l}12 \cdot 37 \\
44 \cdot 38\end{array}$ & $\begin{array}{l}16 \cdot 74 \\
60 \cdot 06\end{array}$ & $\begin{array}{l}4 \cdot 82 \\
5 \cdot 06\end{array}$ \\
\hline For amount of food consumed per lb. live-weight gain & 0.177 & 0.244 & 0.330 & 4.34 \\
\hline
\end{tabular}

Thirty Large White weaners from the Shinfield virus-pneumonia free herd were selected from seven litters and arranged in descending order of live weight. Six blocks of five pigs as similar in weight as possible within each block were then selected, the five pigs in each block being allocated at random to the five treatments without reference to litter origin. Males and females were equally represented in each treatment, and the pigs were Io- I I weeks old when the experiment, which lasted 15 weeks, began. Individual feeding was used and there was no direct contact between pigs on different treatments. The pigs were given twice daily as much meal as they would consume within $30 \mathrm{~min}$ up to a maximum of $7 \mathrm{lb}$./day, water at the rate of $3 \mathrm{lb}$. to every $\mathrm{lb}$. of meal being added to the meal immediately before feeding. 


\section{RESULTS}

The results are given in Table 2. During the 4 th week of the experiment, two pigs, one on treatment $I$ and one on treatment 5 , went off their food and had slightly elevated body temperatures. They quickly responded, however, to a single intramuscular injection of 900,000 units of penicillin. During the first 3-4 weeks of the experiment most of the pigs on treatment 5 passed very loose dung, and their growth rate was to some extent retarded. Thereafter the faeces became normal in consistency and the pigs continued to thrive. The figures in Table 2 show that the pigs on treatments $2-5$ all grew at a significantly faster rate than the control pigs on treatment $\mathrm{I}$. The differences in rate of gain between the pigs receiving the various supplements on treatments $2-5$ were not significant. The pigs on treatments 2 and 3 consumed significantly more food than both the control pigs and those on treatment 5 . The differences in the amounts of food consumed by these two last groups and by pigs on treatment 4 did not quite reach the $5 \%$ level of significance.

The efficiency with which the pigs on treatment 5 utilized their food was significantly better than that of the pigs on treatments $I$ and 2 and better, although not quite significantly so, than that of pigs on treatments 3 and 4 . None of the other differences in food utilization were significant.

Grading results in a commercial bacon factory indicated no significant differences in carcass quality between any of the five groups of pigs, all except three, which graded B, being grade A carcasses.

\section{DISCUSSION}

These results show that all four supplements were equally effective in increasing the rate of gain of the pigs. It appears, however, that whereas the increased rate of gain by those pigs receiving the mineral mixture XF or Aurofac $2 \mathrm{~A}$, either alone or in combination, was the direct result of an increased food consumption with no significant effect on the efficiency of food utilization, the higher rate of growth of the pigs given copper sulphate alone was due to a significant improvement in their food-conversion rate.

As was previously observed (Barber et al. 1955), the differences in growth between the control animals and those on treatment 2 , and also those on treatments 3 and 4 , were established during the first 8 weeks of the experiment, during which time these three groups all consumed more meal and utilized their food more efficiently than the control pigs. Contrary to the previous test (Barber et al. 1955), the pigs in the present experiment were all free from virus pneumonia, so the suggestion previously made that the failure of the supplemented pigs to maintain a higher rate of growth than the control animals during the latter half of the experiment was due to the virus-pneumonia infection is not substantiated. The pigs receiving the copper-sulphate supplement alone, on the other hand, grew faster and utilized their food more efficiently than the control animals during both the first 8 weeks and last 7 weeks of the experiment, in spite of the period of scouring and slow growth in these pigs which occurred early in the trial. 
Although significant treatment differences were obtained in this single experiment, the small number of animals used must be borne in mind, and it is clear that additional work is required before any definite conclusions can be drawn. Further experiments, in which the effects of copper sulphate and antibiotic supplements in the diet of fattening pigs are being compared, are now in progress.

\section{SUMMARY}

I. Thirty individually fed Large White fattening pigs, IO-I I weeks old at the beginning of the experiment, were used to compare the effects of dietary supplements of a high-copper mineral mixture, aureomycin or copper sulphate on rate of gain, food consumption and efficiency of food utilization.

2. The high-copper mineral mixture and aureomycin, either alone or together, and the copper-sulphate supplements were equally effective in significantly increasing the rate of gain of the pigs.

3. The increased rate of gain arising from the use of the mineral mixture or aureomycin was due to a significant increase in food consumption, there being no significant effect on the efficiency of food utilization.

The food consumption of the copper-sulphate supplemented pigs was, however, not significantly increased, the increased gain being due to a significant improvement in the efficiency of utilization of the food consumed.

4. None of the treatments had any significant effect on the commercial bacon factory grading of the carcasses.

We acknowledge with thanks the gift of the mineral mixture XF and copper sulphate from Minsal Ltd, Northwich, Cheshire.

\section{REFERENCES}

Barber, R. S., Braude, R., Kon, S. K. \& Mitchell, K. G. (1953). Brit. f. Nutr. 7, 306.

Barber, R. S., Braude, R. \& Mitchell, K. G. (1953). Chem. E' Ind. p. 410.

Barber, R. S., Braude, R. \& Mitchell, K. G. (1954). Chem. E' Ind. p. 76.

Barber, R. S., Braude, R., Mitchell, K. G. \& Cassidy, J. (1955). Chem. EO Ind. p. 6or.

Bowler, R. J., Braude, R., Campbell, R. C., Craddock-Turnbull, J. N., Fieldsend, H. F., Griffiths, E. K., Lucas, I. A. M., Mitchell, K. G., Nickalls, N. J. D. \& Taylor, J.H. (1955). Brit. F. Nutr. 9, $35^{8}$. 